УДК $378: 316.48$

DOI:

Борис Савчук, доктор історичних наук, професор кафедри педагогіки та освітніх технологій імені Богдана Ступарика Прикарпатського національного університету імені Василя Стефаника

Наталія Салига, кандидат педагогічних наук, доиент кафедри педагогіки та освітніх технологій імені Богдана Ступарика Прикарпатського національного університету імені Василя Стефаника

\title{
РЕЦЕПЦІЯ ФЕНОМЕНУ ПЕДАГОГІЧНИХ КОНФЛІКТІВ ЗАХІДНИХ НАУКОВЦІВ У МОДЕЛЮВАННІ ПРОФЕСІЙНОЇ ПІДГОТОВКИ ФАХІВЦЯ
}

Визначено пріоритети дослідження педагогічних конфліктів у західній науці та представлені в ній підходи і методики формування конфліктологічної культури студентів. При осмисленні проблематики педагогічних конфліктів зарубіжні дослідники спираються на міждисциплінарний досвід вивчення конфліктології. Одним із пріоритетних напрямів таких студій стали т. зв. "маргінальні" групи студентської молоді (представники етнічних меншин, особи з обмеженими можливостями здоров'я тощо), які часто стають джерелами виникнення конфліктів.

Ключові слова: педагогічний конфлікт; педагогічна конфліктологія; конфліктологічна культура; науковий дискурс; професійна підготовка майбутніх учителів.

Jim. 7.

Borys Savchuk, Doctor of Sciences(History), Professor of the Pedagogy and Educational Technologies Department named after Bohdan Stuparyk Vasyl Stefanyk Precarpathian National University

Natalia Salyha, Ph.D.(Pedagogy), Associate Professor of the Pedagogy and Educational Technologies Department named after Bohdan Stuparyk Vasyl Stefanyk Precarpathian National University

\section{RECEPTION OF THE PHENOMENON OF PEDAGOGICAL CONFLICTS OF WESTERN SCIENTISTS IN SIMULATION OF PROFESSIONAL TRAINING OF THE FUTURE SPECIALIST}

The article reveals the reception of the phenomenon of pedagogical conflicts of western scientists in simulation of professional training of the future specialist, contemporary approaches to the essence of conflict have been clarified, the subject of conflict science (conflictology) has been identified. The concept of conflicts that exist in conflicting literary sources is covered. In the article, on the basis of the analysis of representative works of foreign scientists the priorities of research of pedagogical conflicts in the western science are defined and the approaches and methods of formation of conflict culture in the context of modeling the training of future professionals.

It is shown that in understanding the problems of pedagogical conflicts, foreign researchers rely on the interdisciplinary experience of studying conflictology by representatives of various fields of knowledge and seek productive ideas, theories to explain the phenomenon of pedagogical conflict and methods and techniques. One of the priority areas of such studies were the so-called "marginal groups" of student youth (representatives of ethnic minorities, people with disabilities, etc.). Due to the "features of identity", they often become sources of conflicy. Two main vectors of Western discourse on the nature and consequences of pedagogical conflicts are characterized. One group of scholars argues that they a priori negatively affect the development of the educational process, so their occurrence should be prevented in any way, and in the solution in any way seek to reach a compromise between the participants. The second group of authors proves the naturalness and regularity of pedagogical conflicts in the educational process and the implementation of various cultural and social initiatives. Therefore, they can not be avoided, and should be used in the formation of conflict experiences between teachers and students. G. Anzaldua's concept of "Border / La Frontera" as a place of existence of different points of view, which question the basic ideas and principles of identity inherited from the family, education system and different cultures, is actualized in Western scientific discourse.

Keywords: pedagogical conflict; pedagogical conflictology; conflict culture; modeling of professional training of the future specialist; an educational institution.

П остановка проблеми. Перехід від притаманної постіндустріальному суспільству адаптивної моделі вищої освіти до якісно нової, характерної для

(C) Б. Савчук, Н. Салига, 2021 інформаційного суспільства, актуалізує потребу підготовки фахівців, які б не тільки володіли фундаментальними науковими знаннями, навичками, уміннями, але й були сформовані як 


\section{РЕЦЕПЦІЯ ФЕНОМЕНУ ПЕДАГОГІЧНИХ КОНФЛІКТІВ ЗАХІДНИХ НАУКОВЦІВ У МОДЕЛЮВАННІПРОФЕСІЙНОЇ ПДГОТОВКИ ФАХІВЦЯ}

особистості $[6,4-5]$. Вони мають сприймати нові ідеї і вимоги, бути чутливими до інновацій та готовими до співпраці за різних умов у різних соціальних і поліетнічних середовищах. Тому серед соціально значущих якостей майбутнього фахівця вагоме місце посідає формування конфліктологічної культури, яка передбачає толерантне ставлення до людей різних поглядів, уподобань, ідейних орієнтацій тощо.

За такої постановки проблеми у розробці нових моделей підготовки майбутніх фахівців варто активно використовувати продуктивний досвід західної гуманітаристики щодо вивчення i врегулювання конфліктів у різних типах освітніх закладів і соціальних середовищах. Важливим кроком на цьому шляху може стати вивчення репрезентативних оригінальних студій з проблем педагогічних конфліктів, які дають цікавий досвід і орієнтири щодо розв'язання означеної проблеми.

Аналіз останніх досліджень. Проблеми моделювання професійної підготовки фахівців в умовах євроінтеграції та реформування освітньої системи України стали предметом широкого наукового дискурсу українських учених (І. Бойчук, С. Вітвицька, О. Герасимчук, Ю. Запорожцева, О. Ковальчук,А. Казмерчук, Н. Колесник,Ю. Корнійчук, С. Кубрак, О. Мірошніченко, Я. Сікора, В. Танська, О. Усата та ін.). У такому контексті активізувалося вивчення сутності й особливостей педагогічних конфліктів у різних типах закладів освіти (Ф. Василюк, Л. Воробйов, Т. Драгунов, В. Журавльов, К. Левітан, Л. Мітіна, М. Мосьпан) та становлення педагогічної конфліктології як окремої галузі знань (С. Баникіна, Н. Грішина, С. Ледер). Утім, вивчення західного досвіду 3 теоретичного обгрунтування і практичного врегулювання педагогічних конфліктів залишається помітною прогалиною в розвитку психолого-педагогічної науки України.

Мета дослідження: на основі аналізу репрезентативних праць зарубіжних учених актуалізувати представлені в них підходи і методики формування конфліктологічної культури майбутніх фахівців як важливого складника моделювання їхньої професійної підготовки.

Виклад основного матеріалу. Як випливає 3 аналізу низки репрезентативних праць зарубіжних дослідників педагогічної конфліктології [1-3; 5; 7], вони орієнтовані на пошук відповідей на питання: “У чому полягає сутність конфлікту, як його визначати?”; “Як викладається / необхідно викладати проблеми конфліктів у процесі підготовки фахівців з різних галузей знань, зокрема майбутніх педагогів?”; “Як учителі, лідери, фасилітатори ставляться до конфліктів та як вони намагаються їх розв'язувати?”. У західній гуманітаристиці точиться конроверсійний дискурс щодо розуміння сутності конфліктів в освітньому середовищі та випрацювання наукотеоретичних ідей і практик їхнього врегулювання. Його учасники - учені, педагоги-практики, здобувачі освіти, громадські діячі - пропонують безліч традиційних та інноваційних теоретичних конструктів і технологій щодо запобігання та розв'язання конфліктних ситуацій у процесі професійної підготовки юнацтва в різних типах освітніх закладів.

Було виявлено, що в процесі осмислення проблематики педагогічних конфліктів західні дослідники спираються на міждисциплінарний досвід розвитку конфліктології, тож представники різних галузей знань шукають продуктивні ідеї, теорії та методики і техніки для пояснення феномену педагогічного конфлікту та шляхів його врегулювання. Одним із пріоритетних напрямів таких студій стали т. зв. маргінальні групи студентської молоді (представники ЛГБТ спільноти, етнічних меншин, особи з обмеженими можливостями здоров'я тощо). Через “особливості ідентичності" вони часто стають джерелами виникнення конфліктів, адже з різних позицій відрізняються та протиставляються “більшості” здобувачів освіти.

Важливе місце у формуванні західної теорії педагогічних конфліктів посідають надбання Л. Козера і Г. Сіммелла, які вважали конфлікт природною і необхідною частиною суспільства та обгрунтували його функціональні наслідки. У визначенні Л. Козера конфлікт трактується як боротьба за цінності, статус, владу й обмежені ресурси, у яких конфліктуючі сторони конфлікту прагнуть не лише отримати бажане, а й нейтралізувати, завдати шкоди своїм суперникам, усунути ї. У такому розрізі крізь призму ретроспективи суспільного розвитку вчений виклав фундаментальні характеристики міжгрупових і внутрішньогрупових конфліктів [4, 232].

На відміну від пострадянської науки, яка у вивченні педагогічних конфліктів акцентує на ㄲï доробку про психофізіологічні, ціннісні, емоційні аспекти людської поведінки, західні науковці розглядають іï передусім у площині управління конфліктами. У такому руслі вони шукають відповіді на запитання: "Як створюються і формулюються знання про конфлікт?”; “Як конфліктологічні знання слугують учасникам освітнього процесу?”; “Як конфлікт пов’язаний з ідентичністю людини?”; “Яку роль має відігравати конфліктологічна культура в 


\section{РЕЦЕПЦЯ ФЕНОМЕНУ ПЕДАГОГІЧНИХ КОНФЛІКТІВ ЗАХІДНИХ НАУКОВЦІВ У МОДЕЛЮВАННІПРОФЕСІЙНОӤ ПІДГОТОВКИ ФАХІВЦЯ}

професійномузростанні майбутнього й дипломованого фахівця?" та ін. [2; 5].

З позицій управління конфліктами розглядається одна 3 принципових концептуальних проблем педагогічної конфліктології. Ідеться про перегляд сформованого у 80-х рр. ХХ ст. (Г. Дойч, М. Джонсон, М. Фішер та ін.) “негативіського” підходу трактування соціальних конфліктів, який акцентував на їхній винятково деструктивній сутності і наслідках [3]

Таким теоріям кинув виклик американськоканадський культуролог, один із засновників т. зв. критичної педагогіки Г. Жіру. Піддаючи ревізії панівні в системі шкільної освіти першої половини 90-х рр. ХХ ст. теорії “гегемонії безконфліктності”, він доводив, що через намагання утвердити консенсус у стосунках з учнями та взаєминах між учнями вчителі ставили “критику конфлікту в центр своїх педагогічних моделей”. А натомість вони мали б виступати арбітрами в таких суперечностях і формувати у такий спосіб досвід конфліктологічної поведінки в себе і в учнів [3, 62-64].

Розвиваючи ідеї Г. Жіру, Т. Гутьерез-Шмич під кутом власних поглядів синтезувала важливі положення західної рецепції педагогічної конфліктології. Дослідниця стверджує, що більшість теорій і стратегій врегулювання конфліктів спрямовані на "заспокоєння клімату" в освітньому середовищі, тому вони часто не забезпечують соціальних змін. 3 огляду на аналіз “мультикультурної” літератури, вона резюмує, що науковці здебільшого розглядають конфлікт як таке, чого варто “усіляко уникати, а не використовувати як можливість”. Конфлікти між викладачами та студентами відбуваються на різних рівнях та в різних “антирепресивних контекстах”, однак їх зазвичай сприймають як “негативний досвід”. Тому основні зусилля спрямовуються на “запобігання та усунення конфліктів”, для чого використовуються різні стратегії [2, 29-30].

Синтезуючи широкий спектр поглядів на конфлікти, які мають місце в процесі професійної підготовки юнацтва в університетах, Т. ГутьерезШмич стверджує, що вони “природні”, адже “присутні щоразу, коли ми беремо участь у важливому проєкті”, зокрема й такому, як навчання студентів. Однак необхідно розрізняти конфлікти як “прості аргументи”, що закономірно супроводжують робочий процес, та конфлікти на ідеологічному і політичному грунті, які спричинені проявами расизму, сексизму, гомофобії, іншими формами системного пригноблення [2, 29-30].

Другий пріоритетний аспект західної рецепції педагогічної конфліктології, що стосується т. зв. маргінальних груп здобувачів освіти, значно слабше актуалізований в українській психологопедагогічній науці. Їх передусім ідентифікують 3 представниками ЛГБТ спільноти, етнічних меншин, а також особами 3 обмеженими можливостями здоров’я. У студіях з цієї проблем [1-2; 5-7] до “маргінальних" груп або “груп ризику” зараховують студентів геїв, лесбіянок, бісексуалів, трансгендерів та квір (англ. queer буквально “дивний”, “своєрідний” - спершу так називали осіб, що не були гетеросексуалами, відтак цей термін почали застосовувати в назвах навчальних дисциплін та дослідницьких напрямів, приміром, квір-теорії), а також студентів із різним кольором шкіри (“студенти-кольори”) та 3 обмеженими можливостями. Стверджується, що вони відчувають високий рівень знущань, переслідувань, фізичного насильства, тому часто взагалі не навчаються в школі. Це свідчить про "глибокі системні проблеми" у системі освіти, зокрема США, яка створює й підтримує такий “насильницький досвід та академічні диспропорції” $[2,31]$

У сучасній західній гуманітаристиці існує розмаїття підходів, ідей, концептів та технік і методик щодо теоретичного осмислення і практичного розв'язання означеної проблеми. Піддаються критиці самі терміни "маргіналізовані студенти”, “студенти ризику” і т. ін. як несприйнятні ярлики, що підкреслюють їхню “інакшість” та в невигідному, негативному світлі вирізняють і протиставляють їх “домінуючій ідентичності” більшості студентів, яка ідентифікується як “біла, гетеросексуальна та дієздатна". Збереженню такого становища сприяе сама школа, яку не можна вважати “нейтральним середовищем”, де панує дух терпимості, лояльності, конструктивізму і рівності. Так само й викладачі, незважаючи на артикуляцію їхньої “аполітичності”, толерантності, не завжди відповідають концепції педагога, який “пропонує неупереджену навчальну програму” та реалізує їі “через неупереджену практику" [7].

У західному освітньому та науковому середовищі дискутується широкий комплекс ідей, підходів, стратегій щодо запобігання, уникнення та врегулювання конфліктів у вищій школі, які виникають через соціальні, етнічні, статеві, інші відмінності між студентами. Для цього пропонуються численні програми з вимогами змін у системі освіти та діяльності педагогів і самого юнацтва. Однією 3 інновацій 2010-х рр. стало моделювання освітніх стратегій підтримки статусу “учителя-адвоката / активіста”, який би не лише зберігав його нейтральність і 


\section{РЕЦЕПЦИЯ ФЕНОМЕНУ ПЕДАГОГІЧНИХ КОНФЛІКТІВ ЗАХІДНИХ НАУКОВЦІВ У МОДЕЛЮВАННІПРОФЕСІЙНОӤ ПДГОТОВКИ ФАХІВЦЯ}

неупередженість у стосунках 3 “різними” студентами, а й міг кинути виклик тим, хто порушує ідеї та практики збереження рівності і толерантності між ними в шкільних середовищах. Вони орієнтують на формування в педагогів готовності і здатності самостійно шукати і випрацьовувати “соціально справедливі альтернативи” чинним традиціям і порядкам, які сприяють збереженню стереотипних поглядів щодо соціальної, етнічної, расової, статевої “різності” студентів як головного джерела напруги і конфліктних стосунків між ними. Таким чином, толерантність і виваженість мають стати обов'язковим компонентом професійної компетентності вчителя та його особистих поглядів і переконань [2; 7].

Роз'яснювальна і виховна робота з-поміж студентів у цьому напрямі здебільшого спрямована на "обхід і мінімізацію ворожості, звинувачень і помсти”. Проведення у такому ракурсі навчання і бесід дає лише тимчасові результати, бо така тактика часто суперечить i ставить під загрозу реалізацію ключових цілей і принципів розвитку мультикультурного суспільства. Натомість потрібна організація справжніх міжгрупових діалогів із критичним аналізом соціальної несправедливості та відвертих розмов про проблеми соціальних утисків. Поряд iз цим варто вивчати потреби й бажання учнів, їхні особисті почуття та наслідки їхньої маргіналізації. Розв’язання цієї складної політичної і педагогічної проблеми передбачає розроблення i реалізацію комплексного підходу щодо забезпечення антидепресивних стосунків між усіма учасниками освітнього процесу [2, 29-30].

Означені ідеї і підходи змінюють та модифікують самі уявлення про феномен педагогічного конфлікту. Вони відсувають на задній план з'ясування його позитивних та / або негативних наслідків. На перше місце постає питання про “різні ідентичності” студентів і самих педагогів, які позначаються на всьому розмаїтті стосунків між ними в освітньому середовищі університету та поза його межами.

У розробленні моделей підготовки майбутнього фахівця заслуговує на увагу представлена Г. Анзалдуа концепція "Прикордоння / Лафронтера”, створена на основі “автоісторії” як способу розробки соціальної теорії 3 використанням автобіографії, вбудованої в історичні події. Авторка змалювала зону Лафронтеру як “місце трансформації, де існують різні точки зору, які вступають у конфлікт між собою та піддають сумнівам базові ідеї і принципи ідентичності, успадковані від сім'ї, системи освіти та різних / своїх культур". Лафронтера постає як прикордоння, у якому особа прагне знайти рівновагу між зовнішнім вираженням змін та внутрішнім ставленні до дійсності. Життя у прикордонні між культурами дає нове розуміння культури з точки зору “однієї та іншої” / “своєї” та “чужої”. Сприйняття двох та більше різних позицій одночасно робить їх більш прозорими, зрозумілими [1].

Оригінальний концепт “конфліктної педагогіки” запропонувала згадувана Т. Гутьерез-Шмич. Синтезувавши різні ідеї та погляди на “ідентичність як засіб для глибокого вивчення соціальних відмінностей і створення нових ідей, переконань й ідентичностей”, дослідниця виклала оригінальну модель формування конфліктологічної культури майбутніх педагогів, яка може бути продуктивною для проведення науковотеоретичних й експериментальних студій в Україні.

Становить інтерес напрацьована Т. ГутьерезШмич теоретична модель формування конфліктологічної культури майбутнього вчителя, що має три найбільш продуктивні, з нашого погляду, складники. Перший-це постструктуралізм, який передбачає відмову есенціалістських (лат. essentia - сутність, буття - вчення про приховану сутність людини) концепцій ідентичності педагога й учня та орієнтує на виявлення “реальної людської природи” як сукупності знань про людину як “об'єкта реального походження”, сформованого в процесі історичного розвитку [2, 39-40].

Другий складник - це теорія квіру, що грунтується на ідеї вивчення “особистості вчителя 3 позицій його взаємин з учнями та ставлення до навчальної програми”. Намагаючись усунути “нормативне розуміння людської природи” і “нормативність навчальних програм”, теорія квіру передбачає потребу усвідомлення “множинності людської сутності (ідентичності) та множинності (мультикультурності) навчальних програм”. У практичній площині вона орієнтує на збір даних про “нестабільність (мінливість) суб”єктів освітнього процесу”, що спричиняє закономірні конфліктні ситуації в його розвитку. Зважаючи на це, формування конфліктологічної культури потребує використання різних / “багатокультурних" навчальних програм [2, 40-41].

Важливе підгрунтя для розв'язання цього завдання дає третій складник у вигляді комплексної діагностичної методики крос-кейсів. Вона передбачає нагромадження емпіричного матеріалу на основі проведення інтерв'ю 3 учителями; ведення польових журналів; збір матеріалів і артефактів про характер освітнього 


\section{РЕЦЕПЦІ ФЕНОМЕНУ ПЕДАГОГІЧНИХ КОНФЛІКТІВ ЗАХІДНИХ НАУКОВЦІВ У МОДЕЛЮВАННІ ПРОФЕСІЙНОЇ ПІДГОТОВКИ ФАХІВЦЯ}

процесу; системного спостереження за конфліктними ситуаціями, що виникають у його розвитку; використання своєрідних методик оброблення та аналізу зібраних даних. Доволі перспективною вважаємо методику зібрання відповідей учителів на “заплановані” (тобто передбачувані) конфлікти, які можуть виникнути у процесі викладання певної навчальної дисципліни. Вона передбачає превентивне визначення ідей, підходів, методів і прийомів діяльності в міжособистісних конфліктах, які можуть виникати в навчальному процесі та під час виконання різних громадських педагогічних ініціатив (збирання пожертвувань, організація зустрічей тощо). Особлива увага звертається на вивчення професійного й особистого конфліктологічного досвіду педагога, що виявляється у відчуттях, роздумах і переживаннях дискомфорту, напруги, які мали місце під час конфліктної взаємодії [2, 40-41].

Висновки та перспективи подальших досліджень. Запропонований аналіз досвіду західної педагогічної конфліктології може бути доволі продуктивним для моделювання процесу професійної підготовки майбутнього фахівця України. Це стосується його міждисциплінарної науково-теоретичної основи у вигляді базових підходів щодо розуміння сутності і наслідків суспільних конфліктів. Доволі продуктивними і перспективними для творчого використання в професійній підготовці майбутніх учителів та діяльності дипломованих педагогів є методики, які передбачають визначення превентивних дій $і$ заходів у конфліктних ситуаціях, які можуть виникати у стосунках між викладачем і студентом та самими студентами

Означені положення зумовлюють потребу подальшого поглибленого дослідження напрацьованих західними дослідниками продуктивних методик і технік формування конфліктологічної культури педагогів і здобувачів освіти для їхньої апробації і творчої реалізації в моделюванні процесу професійної підготовки майбутніх фахівців у руслі реформування системи освіти України та їі інтеграції в європейський культурний простір.

\section{ЛІТЕРАТУРА}

1. Anzaldua G. Borderlands / Lafrontera: The new mestiza. San Francisco: Aunt LuteBooks, 1987.201 p. URL: http://users.uoa.gr > (дата звернення 21.02.2021).

2. Gutierez-Schmich T. Public Pedagogy and Conflict Pedagogy: Sites of Possibility for Anti-Oppressive Teacher Education. A dissertation Presented to the Department of Education Studies and the Graduate School of the University of Oregon in partial fulfillment of the requirements for the degree of Doctor of Philosophy. 2016.
293 p. URL: https://scholarsbank.uoregon.edu > GutierezSchmich. (дата звернення 20.04.2021) (дата звернення 20.04.2021).

3. Giroux H. A. Disturbing pleasures: Learning popular culture. New York: Routledge, 1994. 256 p. URL: https:// www.taylorfrancis.com > (дата звернення 20.04.2021).

4. Coser L. A. Conflict: Social aspect. International encyclopedia of the social sciences. New York. Macmillian The Free Press, 1968. Vol. 3, pp. 232-236.

5. Kosciw J. G., Greytak, E. A., Palmer N. A., \& Boesen M. J. The 2013 National School Climate Survey: The experiences of lesbian, gay, bisexual, and transgender youth in our nation's schools. New York: Gay, Lesbian, and Straight Education Network, 2014. 139 p. URL: https:/ /www.glsen.org > sites > default > files > (дата звернення 22.04.2021)

6. Моделювання професійної підготовки фахівців в умовах євроінтеграційних процесів. Монографія / за ред. С. Вітвицької. Житомир: Вид. О. О. Свенок, 2019. 304 с.

7. Smith, M., Payne, E. School professionals' responses to LGBTQ training. The Sage encyclopedia of LGBTQ Studies. New York. Queering Education Research Institute. 2014. URL: www.queeringeducation.org. (дата звернення 21.04.2021)

\section{REFERENCES}

1. Anzaldua, G. (1987). Borderlands / Lafrontera: The new mestiza. San Francisco: Aunt LuteBooks. 201 p. Available at: http://users.uoa.gr > [in English].

2. Gutierez-Schmich, T. (2016). Public Pedagogy and Conflict Pedagogy: Sites of Possibility for Anti-Oppressive Teacher Education. A dissertation Presented to the Department of Education Studies and the Graduate School of the University of Oregon in partial fulfillment of the requirements for the degree of Doctor of Philosophy, $293 \mathrm{p}$. Available at: https://scholarsbank.uoregon.edu > GutierezSchmich. [in English].

3. Giroux,H.A.(1994). Disturbing pleasures: Learning popular culture. New York, 256 p. Available at: https:// www.taylorfrancis.com> (датазвернення 20.04.2021). [inEnglish].

4. Coser, L. A. (1968). Conflict: Social aspect. International encyclopedia of the social sciences. New York. Macmillian The Free Press. Vol. 3. pp. 232-236. [in English].

5. Kosciw, J. G., Greytak, E.A., Palmer, N.A., \& Boesen, M. J. (2014). The 2013 National School Climate Survey: The experiences of lesbian, gay, bisexual, and transgender youth in our nation's schools. New York: Gay, Lesbian, and Straight Education Network, 139 p. Available at: https:/ /www.glsen.org > sites > default > files > [in English].

6. Modeliuvannia profesiinoi pidhotovky fakhivtsiv v umovakh yevrointehratsiinykh protsesiv. Monohrafiia [Modeling of professional training in the conditions of European integration processes. Monograph]. (2019). (Ed.). S. Vitvytska. Zhytomyr, 304 p. [in Ukrainian].

7. Smith, M. \& Payne, E. (2014). School professionals' responses to LGBTQ training. The Sage encyclopedia of LGBTQ Studies. New York. Queering Education Research Institute. Available at: www.queeringeducation.org. [in English]

Стаття надійшла до редакції 20.04.2021 